Całość publikacji poprzedzona została, zgodnie z istniejącym zwyczajem, bibliografią Jubilata za lata 1963 do 2000. Imponująca, zawierająca ponad tysiąc pozycji bibliografia wskazuje na potencjał badawczy Profesora i wciąż nie słabnące siły na drodze dalszych poszukiwań naukowych. Tytuł księgi - Przeszlość odlegla i bliska wyznacza jej zawartość, a zarazem odzwierciedla glówne nurty w drodze badawczej uczonego, która zawiera się między dwiema dyscyplinami - historia i politologią. Nie dziwi więc fakt, że reprezentują je również autorzy artykułów - przyjaciele Jubilata, koledzy, współpracownicy i uczniowie. Nadesłane artykuły pogrupowano w czterech działach tematycznych: Historia, Politologia, Mass media i Varia według nazwisk autorów w porządku alfabetycznym. Nie przypadkowo organizacja konferencji na temat kultury politycznej zbiegla sie z obchodami jubileuszu Profesora Kosmana. Powszechnie wiadomo, iż temat ten jest Jubilatowi szczególnie bliski i wnikliwie poruszany w licznych opracowaniach na temat szeroko pojętej kultury.

Kultura polityczna pozostaje zwykle pod silnym wpływem zjawisk nam wspólczesnych. Nic dziwnego, że właśnie ten element został najmocniej wyeksponowany w referatach składających się na drugi dzień konferencji, który obfitował w jedenaście wystąpień. Otwarcie obrad rozpoczął prof. J. Pảnek z Pragi (Stavovska vize strednii Evropy. Od protiturecke aliance $k$ evangelicke konfederaci). Następnie prof. W.A. Serczyk nakreślił wizje przyszłości w odniesieniu do szans Hadziacza, zaś prof. J. Byliński zaznajomił słuchaczy ze szlacheckimi koncepcjami ustroju Rzeczpospolitej z przełomu XVI i XVII wieku. Dalsze wystąpienia koncentrowały się na kulturze politycznej osiemnastowiecznej Polski (prof. M. Żyromski) a także twórcach graficznych obrazów Śląska (prof. W. Kaczorowski). Walor ponadczasowy miały dociekania nad oceną postaci Augustyna Kordeckiego wygłoszone przez prof. M. Kosmana oraz zarys projektów nowej polityki europejskiej wobec Rosji Stanisława Leszczyńskiego (prof. A.J. Zakrzewski i mgr M. Skwarczyńska). Referat ks. prof. S.Z. Jabłonskiego przybliżył kwestię Jasnej Góry w swiadomości narodowej $X I X$ wieku.

Ostatnie trzy wystąpienia odbiegały od wcześniej wygłoszonych, koncentrowały sį̨ bowiem na omówieniu funkcjonowania wizji przyszłości w kulturze politycznej Polski po roku 1989 i stały się głównym przyczynkiem do ożywionej dyskusji zamykającej obrady. Szczególnie tekst prelegenta K. Borowczyka - Wizje polski przy okraglym stole oraz artykuł A. Kasińskiej - Metryki na temat elit politycznych w Polsce po 1989 roku. Nie było wątpliwości co do zasadności rozważań, powiązań tematów wystąpien z tytułem konferencji: Kultura polityczna w Polsce - wizje przyszlości.

Wielowątkowość omawianych zjawisk podczas spotkań wskazała na potrzebę wspólnych studiów prowadzonych przez reprezentantów różnych dyscyplin humanistycznych. W tym wypadku prym wiedli historycy i politolodzy. Dorobek majowej konferencji stanowi ważny wkład w rozwój badań nad kulturą polityczną. Organizatorzy przygotowują publikację na podstawie zaprezentowanych referatów oraz dyskusji.

Zaneta Polowczyk

\title{
Edukacja 2000. Opozycja: Elitaryzm - Egalitaryzm. Konferencja naukowa WSP w Slupsku, 29-30 maja 2000 r.
}

Wydział Filozoficzno-Edukacyjny WSP w Słupsku zorganizował wraz z oddziałem słupskim Polskiego Towarzystwa Pedagogicznego konferencje naukową na powyższy temat. Obrady odbywały się w Ustce w ośrodku Jantar. Wzięli w nich udział przedstawiciele kilku ośrodków naukowych, m.in. z Bydgoszczy, Częstochowy, Kielc, Koszalina, Krakowa, Katowic, Olsztyna, Poznania, Słupska, Szczecina, Torunia, Trójmiasta, Wrocławia i in. 
Referaty plenarne wygłosili: Lech Witkowski (UMK), Mirosław Szymański (AP - Kraków), Jan Hellwig (UAM - Poznań), Stefan Mieszalski (Uniw. Warsz.), Jerzy Kojkoł (Ak. Mar. Woj. - Gdynia), Elżbieta Sajdak-Michowska (WSP - Słupsk), Teresa Giza (WSP - Kielce).

Obradowały także dwie sekcje problemowe: Elitaryzm - kształcenie wybranych czy przymus posiadania Mistrza? i Egalitaryzm - kształcenie masowe czy przymus kształcenia w społeczeństwie demokratycznym?

W sekcji pierwszej referaty i komunikaty przedstawili: Szczepan Kutkowski (WSP - Kielce), Beata Ecler (U. Śl.), Malgorzata Balukiewicz (U. Śl.), Irena Wolny (U. War.-Maz.), Jarosław Chaciński (WSP - Słupsk), Piotr Jan Przybysz (AMW - Gdynia), Monika Maciejewska (U. War.-Maz.), Mykoła Zymoryna i Dariusz Kalinowski (BWSH - Koszalin), Danuta Żebrowska (UG). Ewa Blińska-Suchanek (WSP - Słupsk), Eugeniusz Borowiec (WSP - Słupsk), Barbara Walasek (WSP - Kielce), Jan Maciejewski (WSO - Wrocław), Jolanta Maciąg (WSP - Słupsk), Aldona Molesztak (WSP - Bydgoszcz), Anna Rożanowska (WSP - Słupsk), Justyna Nowotna (U. Szcz.), Apolonia Suchora-Olech (WSP - Słupsk) i Joanna Szczepankiewicz (WSP - Słupsk) referowały w sekcji drugiej.

Celem konferencji wg założeń organizatorów było spotkanie interdyscyplinarne pedagogów, socjologów, filozofów, a także przedstawicieli innych dyscyplin naukowych zajmujących się problematyką współczesnej pedagogiki i nauk współdziałających.

Rozważając rozmaite problemy szczegółowo skonstatowano, iż pojęcia elitaryzm i egalitaryzm sq̨ w naszej literaturze niejednoznacznie zdefiniowane, a już zupełnie, w szczególności przez polityków, a także organizatorów oświaty, rozumiane i interpretowane. Zagadnienie parytetu w dziedzinie dostępu do edukacji jest problemem odwiecznym i ciągle nierozwiązanym. Czy jego rozstrzygniecie jest $w$ ogóle możliwe?

Zwykle funkcje założone obejmowaly idee egalitaryzmu, które od czasów Rewolucji Francuskiej (1789 r.) i projektu Condorceta były i są bardzo modne i nośne. Są przecież komponentem manipulacji politycznej. Praktyka, czyli funkcja rzeczywista, wyrażała się jednak zawsze w konwencjach elitarystycznych.

Podejmowane w przeszłości prace nad doskonaleniem oświaty wynikały najczęściej z sytuacji politycznej, a nie zawsze pedagogicznej. Skomplikowana problematyka z tym związana nie zawsze była dobrze do końca przygotowana, w szczególności pod względem finansowym. Praca szkoły angażowała społeczeństwo ale w ostatecznym kształcie jego udział był minimalny. Współpraca z pedagogami była częściowa; decydowali politycy, stąd też aktywność specjalistów w miare postępu prac malała. Ciężar reform edukacyjnych spadał na barki mniej lub bardziej przygotowanych do ich spełnienia ale słabo wynagradzanych nauczycieli. W okresie powrotu idei samorządności narosły nowe problemy, w szczególności wokól pytania o metodę przygotowania i przeprowadzenia reform edukacyjnych w warunkach decentralizacji i demokracji, a także sposobów i źródel finansowania.

Materiały $\mathrm{z}$ konferencji będą opublikowane.

Jan Hellwig

\section{Edukacja wobec wielokulturowości. Konferencja naukowa w WSP w Częstochowie, 6 czerwca 2000 r.}

Zakłład Historii i Teorii Wychowania WSP w Częstochowie oraz Komisja Filozofii i Socjologii PAN w Katowicach zorganizowały konferencję pod powyższym tytułem. Celem konferencji była refleksja nad glównymi nurtami pedagogicznymi związanymi z procesem kształcenia i wychowania wielokulturowego na ziemiach polskich i w Polsce XIX i XX w. 